\title{
7 \\ Chanting Diplomacy: Music, Conflict, and Social Cohesion in Micronesia
}

\author{
Brian Diettrich
}

Micronesian societies have placed enormous emphasis on concealing and harnessing conflict and on channeling hostility into positive forms.

(Petersen 2009: 153)

Processes of conflict resolution have a valuable role in facilitating social cohesion in any society. Indigenous cultural forms of diplomacy refer to localised and distinct efforts of conflict resolution, and music and dance may take valuable roles in the establishment of social peace. In the Pacific region, few studies have engaged fully with the place of music and dance in contexts of diplomacy, and the topic remains under-researched. Writing of music broadly, O'Connell notes that 'music occupies a paradoxical position, used both to escalate conflict and to promote conflict resolution' (2010: 10-11). He adds that the power of the performing arts in these situations extends from 'the multivalent potential of music in its practical guise' (ibid.: 2). Following this consideration of the social potential of music in situations of diplomacy, in this chapter I present two examples of indigenous Micronesian chant as approaches to peace. Both examples address problems of social cohesion through performance, and each presents a contrasting means of articulating ideas about peace in Micronesian communities. Through a close reading of the poetics, music, 
and contexts of the two chants, I emphasise the role of music in mediating Pacific societies, and I argue for a greater attention to indigenous music in the establishment of social diplomacy.

One of the earliest efforts to fully understand diplomacy and indigenous musics in Australasia was the work of Stephen Wild, who has advocated closely for indigenous performance practices of social cohesion. Following Stephen's later observation that the 'comparative perspective' was largely absent from ethnomusicology in Australia and the US (2006), in this chapter I take inspiration from his work and explore music for social cohesion in the island societies of Micronesia in the western Pacific. Through this chapter, I also wish to pay tribute to Stephen's leadership in the International Council for Traditional Music, particularly as chair of the Study Group on Music and Dance of Oceania, but also thereafter as Secretary General and Vice President. My familiarisation with Stephen's work came first through his leadership of the Study Group, and when I was a new member and doctoral student. I fondly recall Stephen welcoming me into this group of international Pacific ethnomusicologists. As the chapters in this book admirably demonstrate, music research in the Pacific and Australasia has benefited from Stephen's advocacy for indigenous musics and cultures. I offer this chapter as a tribute to that work and to an increased understanding of indigenous musical practices in the Pacific.

\section{Rituals of diplomacy}

An important body of Stephen Wild's work has been the documentation and interpretation of music and dance for the rom ceremony from northcentral Arnhem Land, Australia. In his edited book Rom: An Aboriginal Ritual of Diplomacy (1986), Stephen used the framework of a 'ritual of diplomacy' to understand rom performance in which participants 'establish or reaffirm friendly relations between different people of different communities and, frequently, of different languages and cultures'. Rom is based on manikay (song series) and combines visual and performing arts. According to Hiatt: 'Rom is the presentation of a bound and decorated pole by a visiting troupe of singers and dancers in response to an invitation from a prominent member of the host community' (1986: 11). The book Rom: An Aboriginal Ritual of Diplomacy documented 'the performance of an Aboriginal ceremony at the Australian Institute of Aboriginal Studies in Canberra in November 1982' (p. xi). It also commemorated a critical performance tradition for the broader public. On the occasion of the 
original performance, Wild wrote: 'Rom in Canberra was a diplomatic initiative by one Aboriginal group to the people of Australia through the mediation of the Australian Institute of Aboriginal Studies' (p. xiii). In the book and in subsequent projects, Stephen's work can be seen in a broader perspective of achieving greater understanding of indigenous cultures and practices in Australasia.

In the insular communities that comprise Micronesia, few studies have documented and examined similar traditions that engage with diplomacy. ${ }^{1}$ Writing about this lacuna in scholarship for Micronesia, Petersen notes: the political skills Micronesians marshal in order to resolve conflict without resort to armed violence have been seriously underestimated by many scholars' (2009: 147-48). In the cultures of the Federated States of Micronesia (FSM), and where people abandoned warfare during the first half of the twentieth century, present-day communities have continued a number of indigenous practices to resolve conflict. These have been led by men and women (Flinn 2010; Marshall and Marshall 1990). Interventions in conflict today are increasingly managed through the church or the court systems with the adoption of Western legal processes (Hezel 2002). Wolff and Braman completed a survey of indigenous conflict resolution and diplomacy for Micronesia. Their study focused on the influence of clan and family disputes and notions of justice within local cultural contexts. According to the authors:

The Micronesian Islanders have developed responses to interpersonal conflict that do not focus so much on individual rights and objective standards of 'justice', but rather on ways for peace to be restored between disputants, as well as the community as a whole ... In Micronesia, a dispute between two individuals is viewed as involving two families. (Wolff and Braman 1999: 120)

Wolff and Braman note that even individual disputes were seen as representative of the larger family and clan. The authors summarised the main indigenous processes for restoring social harmony in Micronesia, but they give no mention to the possible role of oratory, song, or chant, whether as part of the process, as a means of unifying participants, or as a means of codifying past experiences of conflict and resulting peace. Across Micronesia today, island narratives of past fighting and disputes are recounted in spoken tales and songs. There is evidence to suggest that

1 See Watson-Gegeo and White (1990) for case studies of conflict discourse in the Pacific and especially from linguistic perspective. 
music has and continues to play a role in diplomacy. In writing about the value of music in situations of conflict and in particular over speech, O'Connell states: 'While language as prose tends to delimit interpretation according to the partial dictates of authorial intention, music as practice serves to liberate interpretation according to the multiple views of audience reception' (2010: 2). In the examples below, I emphasise that in Chuuk, Micronesia, the performance of poetry-sometimes in specialised language modes-facilitates contexts with a power to invoke social resolution. Following O'Connell, I contend that the contemporary perspectives and receptions of listeners are integral to understanding the influence of cultural practices from the past.

\section{'Wélúmetaw': A chant of peace}

On many islands in Micronesia chants retell, codify, and reflect past experiences of conflict, disputes, and warfare between clans. This music is not just a historical reminder of conflict, but through the moment of performance singers and listeners are able to experience and take part in the resulting peaceful social norms of the 'here and now'. In this first example and in the subsequent section, I explore two forms of vocal music that demonstrate the relationship between music, conflict, and social relations. Detailed descriptions of individual Micronesian music examples have been rarely undertaken since the early twentieth century (Herzog 1932, 1936). While a full accounting of musical styles and types is beyond the confines of this chapter, instead I provide a close reading of the salient features and contexts of two examples from Chuuk State in the FSM. The poetic and musical characteristics of both examples are representative of kéélún lóómw (kéénún nóómw in Chuuk Lagoon), a broad category of traditional music that extends from the cultural past and is socially valued in the present.

The first musical example that I explore is called 'Wélúmetaw', a chant well known in the repertory. 'Wélúmetaw' conveys aspects of past conflict and eventual peace between the islands of Pollap and Tamatam, which are positioned about 11 kilometres apart and share a single atoll lagoon in the central Caroline Islands. ${ }^{2}$ Both Pollap and Tamatam are part of the Western Islands of Chuuk State in the FSM. They share cultural affinities with the other western islands of Polowat and Houk, as well as the atolls

2 In earlier orthographies, Pollap was spelled as Pulap. 
further to the west in Yap State. The communities of Pollap and Tamatam are known throughout Chuuk State for carefully sustaining indigenous music and dance practices (see Figure 1). This is evident with migrants from both atolls that reside on Chuuk's main island of Weno and who frequently perform music and dance for state government functions (Flinn 1992). Of the two islands, some would contend that Pollap maintains a dominant role in the relationship from its status as the larger island. Pollap retains a place in the central Caroline atolls as a possible origin location of traditional navigational practices (Lessa 1980: 39-41). The name 'Tamatam' perhaps explains the relationship between both islands as it comes from the word taam, meaning the outrigger of a sailing vessel (Flinn 1990: 114); thus a secondary but essential partner. ${ }^{3}$ Because of the close proximity between islands and the single, shared lagoon, the clans of both Pollap and Tamatam are closely intertwined historically and today; thus the stories and songs from the single lagoon involve both islands.

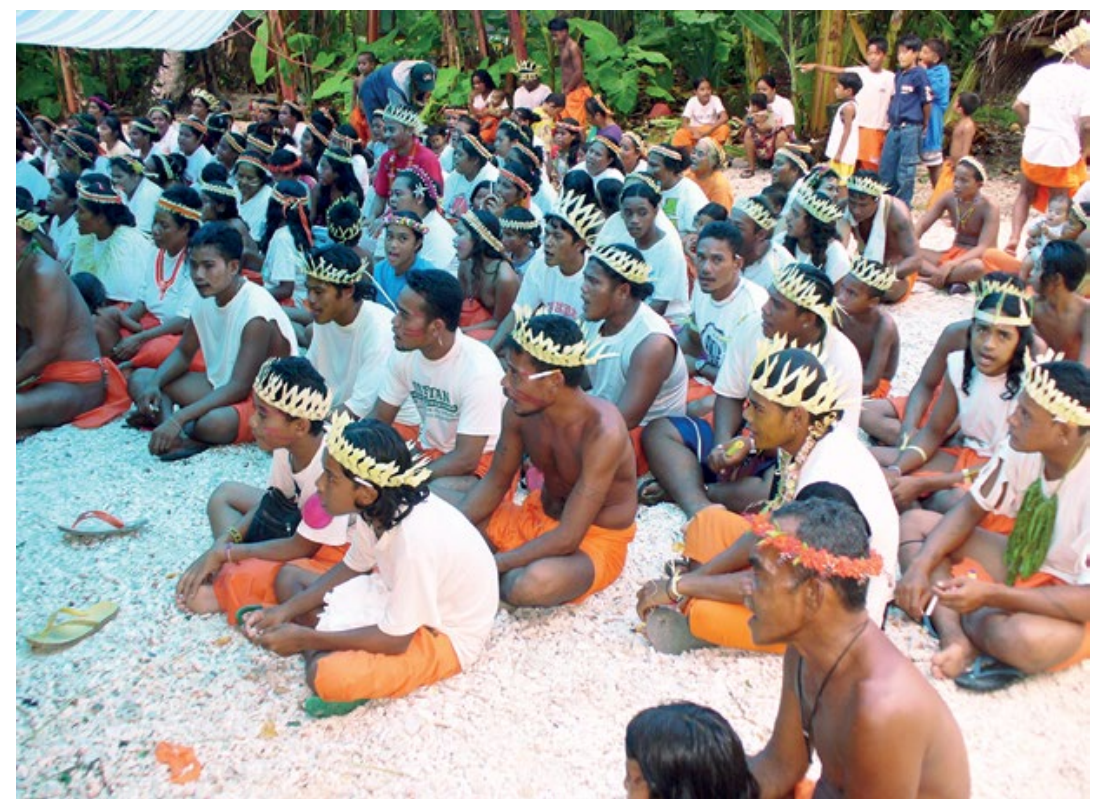

Figure 1. Singing at a community gathering on Tamatam Island Source: Brian Diettrich, 2006

3 Elbert (1972: 172) confirms this reading of the name, but he links Tamatam with Polowat Islands in what is a likely transference of the frequently spoken rivalry between Polowat and Pollap. 
I have heard the chant 'Wélúmetaw' on several occasions. My understanding of it as represented in this chapter comes from past discussions with John Sandy, Elias Sandy, Pedro Limwera, and Rewimen knowledgeable about music and dance from Pollap and Tamatam and the Western Islands region. In synthesising both ethnographic and archival information about 'Wélúmetaw', I also draw on secondary conversations and published sources. I should note from the outset that variations in the music and poetry of the chant, as well as competing stories about it, are dynamic aspects of cultural knowledge in the FSM.

An understanding of 'Wélúmetaw' begins with the title word itself. The term brings together the separate words wélu, meaning 'forest' or 'bush', together with metaw, meaning the 'deep sea' (Elbert 1972: 91, 192; Goodenough and Sugita 1980: 368). ${ }^{4}$ Taken together, the term can be glossed in English as 'sea-forest'. As explained to me on several occasions, the word refers to the sea in the lagoon being blocked or closed off between Pollap and Tamatam (see Figure 2) as a result of conflict. Passage in the lagoon was no longer open without risk of battle or possible death. This blocked character of the shared lagoon is likened to a thick forest of trees-a 'sea-forest'. This is the historical context of the chant.

'Wélúmetaw' has been described as a peace-making chant (Sandy 2001). The text conveys the experience of past conflict and the problematic result that this had for access to the lagoon. The chant is a plea for peace (kinamwmwe) and thus life (manaw). It reinforces the connections between Pollap and Tamatam. Accounts suggest that 'Wélúmetaw' was composed during the late nineteenth century or early twentieth century by Mwariitey, a chief, who was the son of Hetippack. ${ }^{5}$ Mwariitey's mother was unnamed in my conversations. ${ }^{6}$ The dispute apparently occurred first within the clan of Pwéél, at the time the chiefly clan on both Pollap and Tamatam, but the fighting also involved the clans of Sóór and Mwóórh (Mwóóch in Chuuk Lagoon), as mentioned in the chant. According to Sandy (2001), the conflict arose over access to bountiful fishing reefs shared between men of both islands. From Tamatam, the man Rongopwi was said to have led a fight, which resulted in the stories

4 Throughout this chapter I make use of the published orthographies of Goodenough and Sugita (1980) and Elbert (1972).

5 John Sandy (2001) suggested that 'Wélúmetaw' was composed during the German administration (1899-1914).

6 According to Sandy (2001:2), Mwariitey was also a younger brother to the famous navigator Pwekeley, who was also a composer and associated with navigational chants. 
told today about men fighting on beaches and in the shallow seas. In the stories that accompany this chant, Mwariitey was said to have composed it as a means of diplomacy. Pedro Limwera from Tamatam recounted to me how Mwariitey eventually led a group of men from Tamatam across the lagoon to Pollap, where they came not for war, but for peace. The men performed 'Wélúmetaw' for the clan-mates on Pollap. As Pedro related: upon hearing it, people were greatly moved, and thus peace was re-established. In listening to the chant today, people are reminded of the past conflict and that despite this history, Pollap and Tamatam are a united lagoon.

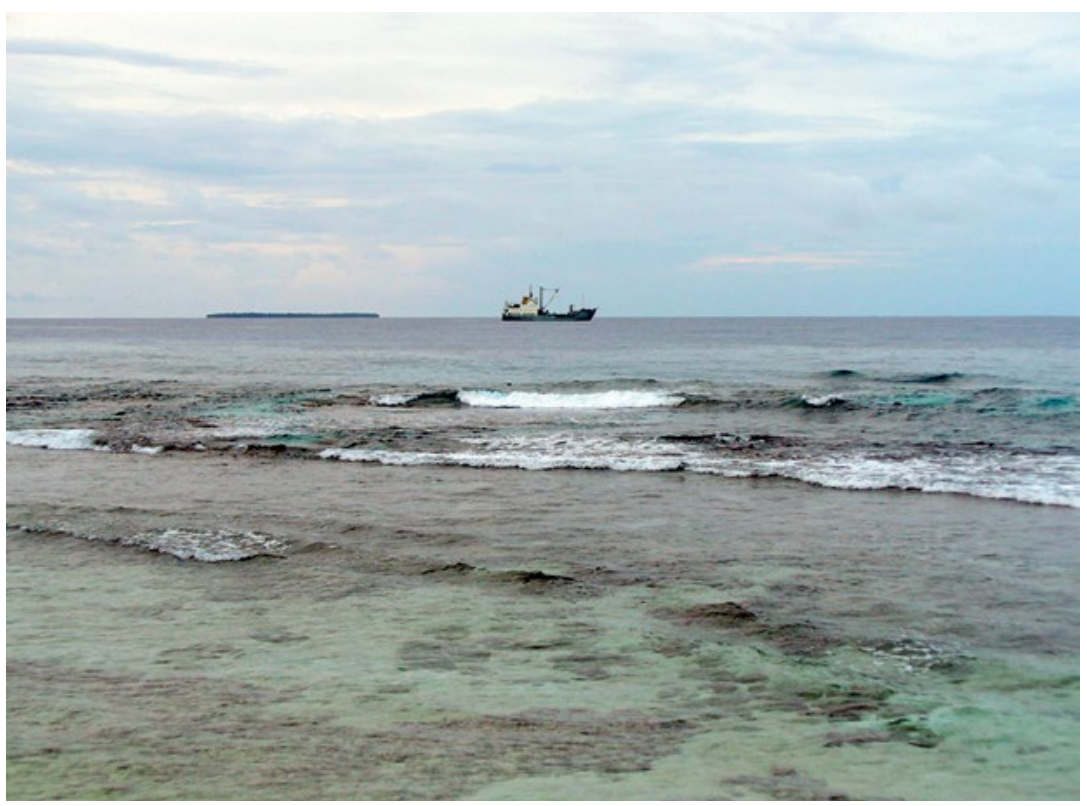

Figure 2. Looking out from the northern beach on Tamatam Island, Pollap Island is shown on the horizon across the lagoon. The ship Chief Mailo lies just off of Tamatam

Source: Brian Diettrich, 2006

The poetry of 'Wélúmetaw' does not record specific dates, nor does it mention the names of individuals, but as a complement to stories about the island past, it conveys the situation from the experience at the time. In the first four lines of the full chant text (below), the narrator hears whispering (angúnungun) and murmuring about the issue at hand: that the lagoon is under a confrontation (line 6). The middle section of the chant (lines 8-14) describes the resulting difficulty of voyaging across 
the lagoon due to the conflict. In the next section, it is Mwariitey, by most interpretations, who emphatically states he will not die as a result of the three clans involved in the dispute: Pwéél, Sóór, and Mwóórh. ${ }^{7}$ The final section of the chant (lines 15-20) invokes the high chief of Pollap and decries that the conflict must be resolved for the continued life (manaw) and thus peace of both communities societies.

1. Imamót lesóópúwúniyól,

2. lóoni fáálicheey,

3. Nge yi rongorong

I was sitting in the evening,

4. angúnúngún wááyi. inside our meeting house, then I heard whispering [criticism] of my expedition.

5. Rangúnúlo rangúnúto, They murmured that way, they murmured this way,

6. pwe siya wélúmetaw that we have a sea-forest

7. lónoyach lóómw.

8. Owu kómóóy wááyi,

9. nge yisopw mo,

10. nge yisopw má, inside our lagoon.

You may attempt to prevent my expedition,

11. pwe yisopw mo, but I will not be eliminated, but I will not die, but I will not be eliminated,

12. yisopw má. I will not die.

13. pwe ree-Pwéél,

14. ree-Sóór, ree-Mwóórh. by the men of Pwél,

15. Nge ifa yi rhék the men of Sóór, the men of Mwóórh.

16. lisou pwóróyisómw? So just where is he,

17. ese áwenató

18. kapaseni fénúach, the great undeterred high chief? who should be directing the rites of our islands, ${ }^{8}$

19. pwe sipwe manaw, so that we will live [in peace], 20. wóón lengi sóónap. on the face of the great earth.

7 According to Flinn (1982: 69), the clan Sóór (Hóór in Puluwatese) originally came to Pollap from Tamatam, but eventually died out in both islands; the clan Mwóórh (Mwóóch in Chuukese) has its roots on Pollap from Namonuito and Tamatam. The clans of Pollap and Tamatam are linked with those of Chuuk Lagoon (see Petersen 2009: 76-77).

8 The phrase kapaseni fénúach literally means the 'language of our island(s)', but it was interpreted to me in the context of the chant as inferring a broader meaning. 
Like the chant repertory throughout the Caroline Islands, melodic variation exists in the pitch and rhythmic content among individual performers. The music transcription of 'Wélúmetaw' (Figure 3) is a representation as performed solo by Pedro Limwera, from Tamatam. From comparisons these performances are representative of the example and the musical style. ${ }^{10}$ The presentation of the poetry is an organising principle for the music of 'Wélúmetaw', but like other chants in Chuuk, performers adapt language from the spoken forms when sung. To assist the delivery of a chant, for example, singers may add or modify vowels at the end of a word, or some less significant words may be omitted. ${ }^{11}$

The melodic content of 'Wélúmetaw' is characterised by a sustained vocal delivery, with a principle tone ( $\mathrm{B}$ in the transcription) approached primarily from below $(G)$ and secondarily from above (D). The pitch content comprises the three tones of a G-major triad (G-B-D), but unlike a triad, the chant's gravity focuses on the centrality of the middle tone (B). The resulting melodic shape provides a grounded stability to the chant and thus a clear communication of the historical narrative. 'Wélúmetaw' is structured into a series of dynamic repetitions of two primary melodic movements: the main one comprising an initial ascent from $G$ to $B$ and then remaining on $\mathrm{B}$; and the secondary one of a descent from $\mathrm{D}$ to B. As these two movements reoccur they bring lift and movement that carry the poetic narrative forward with each successive phrase. The chant rhythm is organised from the text but sometimes in unexpected patterns. In some instances, the rhythm demonstrates a propensity for successive long and short durations (dotted rhythms) that are characteristic of chants from the western islands of Chuuk. A change to abrupt and short rhythmic segments with a pause separating each occurs in lines 8-14. This section coincides with the personal declamations in the text ('I will not be eliminated, I will not die') and followed by the three clan names: Pwél, Sóor, and Mwóórh. This change brings focused attention to the assertive statements by Mwariitey in these phrases. The final three phrases return to a sustained character of the chant before closing.

9 This musical transcription is based on two performances given on 26 July 2006 and 10 December 2014 by Pedro Limwera. The musical transcription represents my transposition of the original pitch content of the performances for ease in viewing.

10 My explanations and music transcriptions using staff notation in this chapter are intended as guide maps that indicate certain elements of sound structure and not as musical documents.

11 In some chant performances in the western islands of Chuuk, the metrical structure of the musical performance is remarkably separate from the textual meter, thus obscuring the words. 


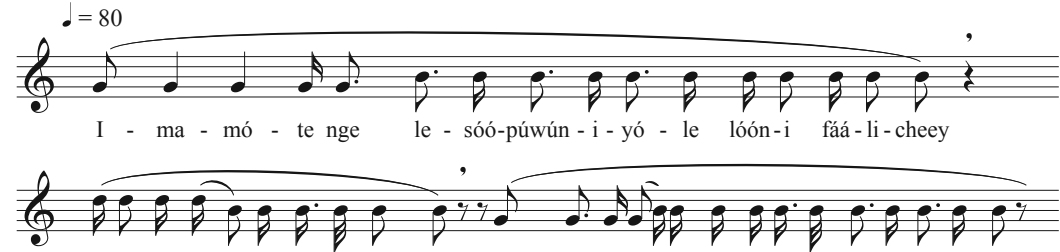

yi ro-ngo-ro-ngo a-ngún-ú-ngún wááyi. Ra - ngún-ú-ló_ra-ngún-ú-to pwe sa wé-lú-me-taw
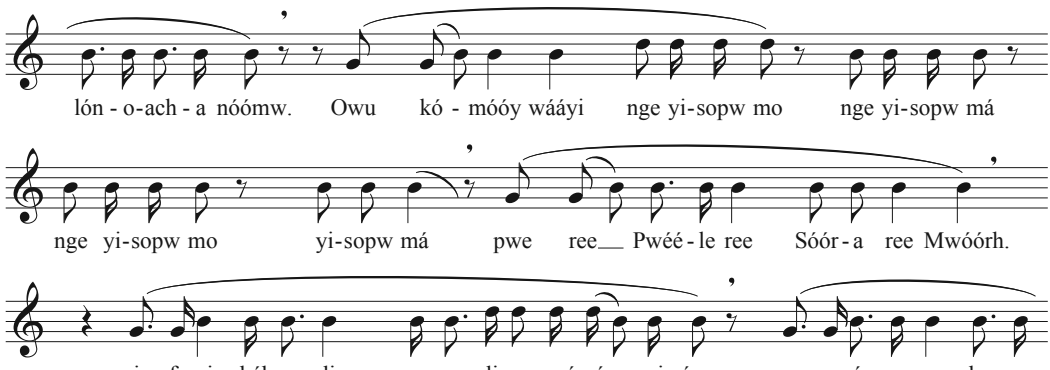

i - fa yi chék-e li - so-wu li-so pwó ró - yi sómw e - se á - we-na ka - pa

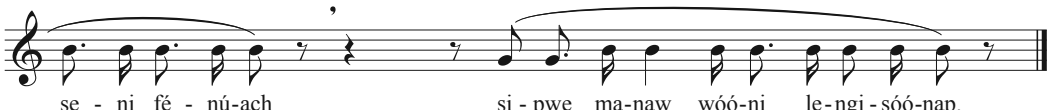

Figure 3. 'Wélúmetaw' (Sea-forest)

'Wélúmetaw' can be performed solo as in the music transcription, but also by a group with dance, in which case it is metered, repeated, and linked together with other successive chants to form lengthy performance segments. The genre of dance associated with 'Wélúmetaw' is called wuiumaaw (stand strong), a dance type for men composed of vigorous movements. ${ }^{12}$ When performed as a wúúmaaw, 'Wélúmetaw' is undertaken in a seated position and organised into rows of performers; emphasis is on the synchronous movements of arms and hands. The example is strongly associated with men, both from the dance genre of wuimaaw but also from the historical contexts of the fighting of men that took place in the narrative between Pollap and Tamatam.

'Wélúmetaw' displays a focused economy in its approach to both music and poetry, and to its engagement with the historical conflict between Pollap and Tamatam. The chant is one piece of cultural knowledge that exists within the larger web of stories and oral history from both islands. In performances of the chant, listeners may recall ancestors and

12 The genre wúumaaw is associated with male performances during the breadfruit season and the associated tasks of this time of year, such as picking breadfruit and fishing (Flinn 1992: 59). 
the accompanying tales about island history, all of which contribute to cultural memory and the value of past events in situations of the present. 'Wélúmetaw' displays a balance in its approach to experience: on one hand it is markedly impersonal without mention of individual names, but on the other hand the poetry is narrated from a personal (and sometimes first-person) perspective in the chant that evocatively brings listeners into its story and thus its larger meaning. The example of 'Wélúmetaw' codifies historical aspects of diplomacy between two islands. By its continued performance, it offers a reflection on past conflict and present-day connections for the people of Pollap and Tamatam.

\section{'Worofes': A rope of life}

In addition to reflecting on events from the past, performances have the potential for more direct interventions in conflict and as a vehicle for restoring peace as well as sustaining social order in communities. For the second example, I discuss a rhythmic recitation called 'Worofes' from the genre known as itang in the high islands of Chuuk Lagoon. The word itang in the language of the lagoon islands of Chuuk refers first to highranking men, knowledgeable about history and cultural practices, and formerly powerful 'political priests' that also led communities in warfare (Goodenough 2002: 368). Secondly, it refers to the knowledge of itang and the form of specialised, esoteric, and cryptic language and its rhythmic recitations. The languages and practices of itang originated in Chuuk Lagoon. A number of separately designated and competing leagues, and communities in the outer islands of Chuuk also maintain aspects of itang and its recitations (Riesenberg and Elbert 1971). Knowledge of itang is mediated by both gender and age: both men and women maintain the knowledge, but it is customary for men to publicly perform the recitations. In addition, elders act as stewards of itang knowledge and recitations. Distinguished by their idiosyncratic and opaque language, itang represent a body of indigenous knowledge that includes information about medicines, language and oratory, local and cultural history, traditional social behaviour and protocols, magic, and formerly warfare (Goodenough 2002: 291-92). The rhythmic recitations are a part of roong (specialised indigenous knowledge) and are strongly linked with manaman (spiritual power). Itang is highly revered by some Chuukese, being associated with traditional social morality, but others perceive it cautiously or negatively from a present-day Christian perspective. 
According to Goodenough, many itang recitations codify protocol for specific social occasions or conflicts, such as disputes over land, conflicts over chiefly succession, conflicts between a chief and a district's people, as well as advice for the general well-being of a community (2002: 31112). For example, Goodenough presents one recitation example called 'Núúkáteete' (Stitched-together coconuts) that was performed in situations 'in which ill feeling between two neighbouring district chiefs was being put away and the two reconciled ... the "stitched" coconuts represented the joining of the two parties back together in harmony' (ibid.: 312). He adds that 'recitation of the piece by the itang speaking for the host chief served to give the sanction of spirit power to the reconciliation symbolised by the offering and acceptance of the coconuts' (ibid.). Metaphor is a favoured aesthetic practice in itang poetry. In 'Núúkáteete', the notion of being stitched together provides a practical and clearly understood idea with which to identify a cohesive society after a period of conflict. The efficacy of itang recitations, however, lies not in the abstract words, but in the rhythmic poetry uttered continuously without break for particular occasions and with the reciter able to harness manaman through the performance. The power of itang poetry comes fully from its performance, which in turn reveals an indigenous context of chanting for desired social outcomes.

One itang recitation that is well known both in Chuuk Lagoon and in the western atolls is called 'Worofes'. I follow and adapt Goodenough's translation of this multilayered word as 'searching look'. ${ }^{13}$ 'Worofes' refers to a specific named recitation, but slightly different versions of it are known throughout Chuuk with variations in the poetry of each that correspond to specific leagues of itang. The version that I describe here was originally recorded in audio form by chief Kintoky Joseph of Udot Island in 1979 for public radio broadcast in Chuuk as part of the Micronesian Music Project. ${ }^{14}$ Unfortunately the reciter was not identified on the recording, but it was likely a man named Kior from Iras village on Weno Island, who was known for his cultural knowledge at that time. The example is from the itang league called Máchewen Sópwunupi that claims its lineage from the legendary Chuukese titled leader Sowuwóóniiras and the high-ranking Sópwunupi clan. This league is furthermore associated with the sacred

13 The term is cautionary and includes what English speakers might say as 'consider deeply' or 'strategise carefully'. A colleague in Chuuk once offered a translation of the term as 'watch out!'

14 The example is found as the second selection on side B of tape 68 of the Micronesian Music Project (1979). The original recording is held at the Music Department of the University of Hawai' $i$ at Mānoa; a copy is located at the College of Micronesia, Chuuk Campus, FSM. A recorded portion of the example is found as track 29 on the CD that accompanies Diettrich, Moulin, and Webb (2011). 
mountain called Tonaachaw above Iras village on Weno Island (Figure 4). When undertaking repatriation of recordings from the 1979 Micronesian Music Project in Chuuk in 2006 and 2007, I discussed this version of 'Worofes' with elders who commented positively on its arrangement and delivery. An initial transcription of the recorded poetry was prepared by Elias Sandy. This led to further discussions about the recitation and its meaning. I subsequently undertook a comparative analysis of this version with four other documented forms of 'Worofes', and I redrafted the text based on this work. ${ }^{15}$ Despite the profile of 'Worofes' as one of the most widely recognised examples in the itang repertory, a detailed version of the poetry in the language of Chuuk has not been published. I therefore present the example below from the original 1979 sound recording as a complement to the other available versions. Individual and creative interpretations are fundamental to itang. The version below adds another layer in a complex cultural discourse.

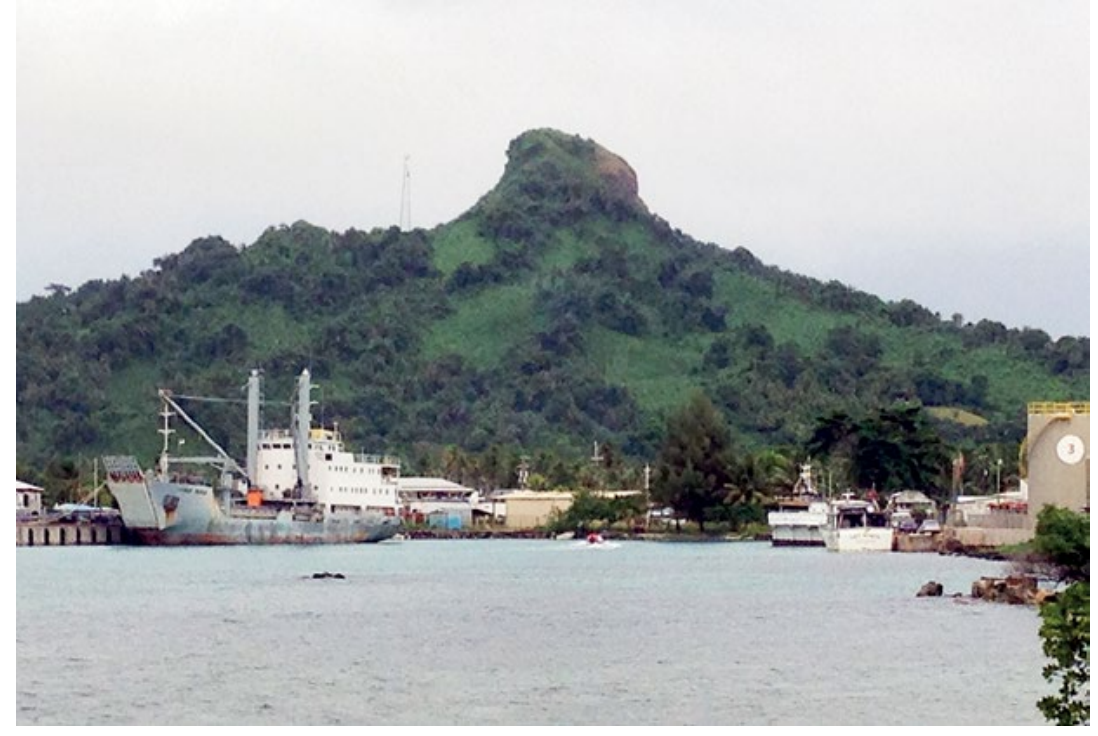

Figure 4. Mt Tonaachaw on Weno Island, a place associated with the origins of itang in Chuuk

Source: Brian Diettrich, 2006

15 These additional versions are: (1) an extended explanation of the text by Goodenough (2002: 310-11); (2) a published text in English (Peck 1992: 88-94); (3) a short published text in Chuukese (Chipen 1979: 433-34); and (4) a recorded version by Rewi (now deceased) of Houk Island from 2006, who offered detailed explanations of its poetry (Diettrich field recording Chk AT.06.43). 
'Worofes' is an especially rich example of itang poetry that also provides a sample of the depth of indigenous Chuukese cultural knowledge. The reciter on the 1979 recording prefaced the example by broadly explaining it as énnúk (laws or rules) related to mwúun (chieftainship or government). Various elders that I spoke with discussed the chant specifically as a form of conflict resolution between chiefs and the populace. For example, Rewi of Houk Island spoke of 'Worofes' to me in 2007 as helien worofes (rope of worofes) and helien manaw (rope of life), terms that link people together as one community. Rewi carefully explained that cutting this metaphorical rope can bring death; thus leaders must find ways to bring people together in times of dispute. The message is that togetherness brings peace and life, but a fractured society can bring chaos and death. ${ }^{16}$ According to Goodenough, the recitation was intended to be performed 'at the time of changing chiefs or of settling disputes between people, between districts, and between chiefs and their people. Its object was to do away with bad thoughts and to create an atmosphere of peace' (2002: 310-11). As the poetry transcription below illustrates, 'Worofes' creates this atmosphere of contemplation by describing an epic journey to both physical and spiritual sites that all together embody the cosmological realm of the islands of Chuuk within the wider Caroline Islands.

The 'Worofes' recitation begins as an imaged journey by sea and with the preparation of an envisaged sailing canoe-a 'canoe-rope' of worofes and, according to Goodenough, a 'divinely designed thought canoe' (2002: 310). The text in lines 4-6 of the transcription below begins what will become a regularly repeated phrase marker in the chant; these lines, along with 4-10, imply a canoe moving from all directions before settling in Chuuk (line 10). The poetry then suggests that chiefs (and perhaps any leader) will receive advice on ruling from many different directions and voices (lines 14-21), but that they should be unwavering like the hardened coral rocks that protrude through the sea along the reef (lines 22-25). The recitation unfolds as a journey that takes listeners across Micronesia to various island destinations mentioned in the text: Fanaanú, Weno and Fanó Islands in Chuuk Lagoon (including various sites on Weno Island), Ulithi, Yap, Pohnpei, Nukuoro, and Kachaw (Kosrae, according to some Chuukese)..$^{17}$ In lines 61-62, we reach Tawanap (Great Pass) at the reef just off of Mechitiw Village on Weno Island, and then to Winikachaw

16 In Chuuk, sennit rope is also a traditional sign and an offering of peace.

17 There is some debate in the literature concerning whether or not Kachaw refers to the island of Kosrae (see Goodenough 1986). 
(Kachaw Place) to drink from the 'sacred spring' located there (lines 63-65) - this is a significant historical and cultural site in Chuuk. The journey continues overseas to a place called Fáánwitonnap (lines 66-74), where the text advises listeners to 'hold the course' (line 75) in the face of Sowumwmwáár (line 77), a legendary titled leader and itang from the rival Mwáánitiw league on Udot Island (Goodenough 2002: 310). Here the recitation reflects the political rivalry between separate associations of itang (ibid.). After this encounter, the canoe takes us to the Wisopw Beach (lines 83-84) on Fanó Island (in Chuuk Lagoon), where we meet Nipéépéénimóng (line 85), a legendary and wise itang, who advises us to drink the 'juice of revelation' (line 91). But the chant ends with uncertainty. Its advice is for careful consideration, seeking out advice but being aware of the turbulence of opinions and politics. 'Worofes' takes listeners aboard a careful and deliberate journey in its use of metaphor and powerful cultural imagery and across the region to places accessible on earth but also of cultural and spiritual significance.

1. Ewúrúrú iye

2. worofes iye

3. seniwaa worofes.

4. Worofes, worofes

5. worofes mé núk

6. worofes mé nóón

7. worofes ssewu

8. nómwun Fanaanú

9. worofes a a nong

10. ne nómwun Chuuk.

11. Worofes, worofes

12. worofes mé núk

13. worofes mé nóón.

14. Ese ngiingi féwúninúk

15. aa ngiingi féwúninóón

16. ese ngiingi féwúninóón

17. al ngiingi féwúninúk
Haul the halyard here, look searchingly here, the canoe-rope of searching-look. Look searchingly, look searchingly look searchingly outside look searchingly inside look searchingly moving northward to the lagoon of Fanaanú ${ }^{18}$ look searchingly southward to the lagoon of Chuuk.

Look searchingly, look searchingly look searchingly outside look searchingly inside. The rocks outside are silent the rocks inside are sounding the rocks inside are silent the rocks outside are sounding

18 An island in Paafeng (the Hall Islands) to the north of Chuuk Lagoon. In itang lore, it is the place where the legendary titled ruler of Weno named Sowuwóóniiras (Lord of the Upper Side of Iras) was killed (Goodenough 2002: 374). This seems to be a particularly poignant reference for the Máchewen Sópwunupi league that claims its origins from Sowuwóóniiras. 
18. ese ngiingi mé wóóyi néwú

19. aa ngiingi mé wóóyi saam

20. $\quad$ ese ngiingi mé wóóyi saam

21. aa ngiingi mé wóóyi néwú.

22. Féwún núkún púngúpúng

23. effenúkú-sómwool

24. nge puwaan me puwaan

25. nge ran mé ran.

26. semeni kepwúngúpwúng

27. nineni kepwúngúpwuing

28. sipwe a pwúngúpwúngúúw

29. annomi rewe

30. éfékúr sómwoon.

31. Ifa ii emwo

32. mwáán ne aroongatam

33. ese féeremwo

34. nge aamwen waa

35. waana worofes.

36. Worofes, worofes

37. worofes mé núk

38. worofes mé nóón

39. worofesinatiw

40. ne nómwun Ulutiw

41. ina na pénúwaa

42. Neechipwen Yap

43. worofesinatá

44. nómwun Fóónupi

45. ina na pénúwaa

46. neechipweni Kachaw. the child is not sounding ${ }^{19}$ the father is sounding the father is not sounding the child is sounding.

The wave-pounded reef-rocks are unwavering like chiefs continuing on day by day. the father of judgement the mother of judgement we will wait for the verdict the child sir the son of the chief.

Where is he the one to direct the canoe it is not corrected the outrigger beam of the canoe the searching-look canoe.

Look searchingly, look searchingly look searchingly outside look searchingly inside look searchingly westward to the lagoon of Ulithi ${ }^{20}$ there the completed canoe is at the site of Yap look searchingly eastward to the lagoon of Pohnpei ${ }^{21}$ there now the completed canoe at the site of Kachaw. ${ }^{22}$

19 Line 18 refers to someone who is dependent and could be read as 'subject' instead of 'child'. I have kept 'child' here because of its alignment with 'father' in line 19. I provide a somewhat literal translation in lines 14-21, but the effect of this section is that one is hearing different advice and 'talk' from everyone (see Peck 1992: 92).

20 An atoll that is part of Yap State.

21 In the Chuukese chant repertory, Fóńnupi is an old Chuukese rendering of 'Pohnpei'.

22 A legendary spirit place in Chuukese lore and often considered by Chuukese today to be the island of Kosrae. See Goodenough (1986) for an alternative perspective. 
47. Worofes, worofes

48. worofes mé núk

49. worofes mé nóón

50. sipwe waanenong

51. wúúnen Kéérawóón

52. wúuneni Kééramwáán

53. sipwe ewúttúwutá

54. ne nómwuyi núk

55. nge si wónongei

56. néwúmi tipwúk

57. ssapani áchenipék.

58. Aa su waa we

59. waana worofes

60. epwe inenong

61. mé mesey Tawanap

62. epwe tiwenongomwo

63. epwe wúnúmi emwo

64. nge chénún rewe

65. nge chénún Winikachaw.

66. Aa su waa we

67. waana worofes

68. epwe túnútiw

69. pacheren féwúwe

70. féwúni núkúni féwú

71. nge épúng mé iyé

72. nge awar mé iyé

73. nge awareta mé

74. Fáánwitonnap

75. sipwe atamatama

76. ikewe rewe

77. néwúni Sowumwmwáár

78. nge emén wupwpwapwech
Look searchingly, look searchingly

look searchingly outside

look searchingly inside

we will sail southward

with the fathers of Kéérawóón ${ }^{23}$

and the feathers of Kééramwáán ${ }^{24}$

we will pull back eastward

at the lagoon of preparation

so we look inward

as a child of sprouting buds

cut off in bloom.

The canoe has departed

the searching-look canoe

it will dock

at the front of Tawanap pass ${ }^{25}$

it will go ashore

it will drink deeply

of the juice sir

so the juice of Winikachaw.

The canoe has departed

the searching-look canoe

it will detach southward

and cling to the rocks

the rocks of outside

so who has judged

so who has arrived

so facing the wind of

Fáánwitonnap

we will hold the course

there sir

subject of Sowumwmwáár

as one white bird

23 According to Peck (1992: 94), an ancient 'hero-warrior' of Kachaw.

24 According to Peck (1992: 94), another ancient 'hero-warrior' of Kachaw.

25 This pass in the reef just off Mechitiw Village on Weno Island has significance in the origin stories of Chuuk (see Goodenough 2002: 319). 
79. epwe nó ruweey

80. ne nómwun Núkúwor

81. nge e wosefáán

82. nge e woranong

83. ew ii wumwunuppi

84. ppiyen Wisopw

85. meta Nipéépéénimóng érá

86. érá wúsopweeytiw

87. érá wúpwetiw

88. wúpwetiw rongo mwo

89. wúpwe wúnúma mwo

90. nge chénúwe rewe

91. nge chénúniyapwáárá

92. nge wú wonongei

93. féwúni nóónii

94. nge a kattiw pwechepwech

95. ese pwing, aa pwing. hurrying towards

the lagoon of Nukuoro ${ }^{26}$

so then look once more

so look southward

to a great sandy beach

the beach of Wisopw

What does Nipéépéénimóng say?

he says to continue westward

he says I will go ashore

I will disembark to listen deeply

I will drink deeply

of the juice sir

so the juice of revelation

so I go on like the

reef-rocks in the waves

and welcome the turbulent waters ${ }^{27}$

it is not correct, it is correct.

Rhythmic recitation is the mode of musical delivery for 'Worofes' and for most examples of itang. In Chuuk, recitation in general is called féeruiyér. It is used for several types of genres, including traditional wayfinding. ${ }^{28}$ Recitation is also known widely in areas of Micronesia and Polynesia (see Fischer and Fischer 1957: 204-5; McLean 1999: 413-14), but with few detailed studies of its use and context. As a separate category of delivery, recitation lies outside the separate domains of speech, oratory, or song. It is usually associated with poetry and language that is culturally significant and sometimes sacred. It creates a focused presentation of the text, with a basic indication of pitch movement to delineate phrases. 'Worofes' and most itang recitations are poetically organised into phrases of eight morae each (Goodenough 1995: 78); thus they divide into regular duple meter. Within this framework, the text-based rhythm uses a variety of changing and subdivided patterns that makes the presentation of itang rhythmically intense and sonically marked. Moreover, as part of performance practice, reciters learn to avoid mistakes or pauses in presentations. Some elder

26 An atoll that is part of Pohnpei State.

27 The word pwechepwech (pwech) describes something white. In the context of the last line of the recitation may mean the 'whitecaps' of ocean waves.

28 Variations exist for this term, such as férúwér and féérúyénu (Goodenough and Sugita 1980: 118). 
performers believe that significant interruptions or mistakes in a recitation can lead to sickness. The sonic result is a continuous and generally quick delivery of rhythmic poetry. ${ }^{29}$ Lengthy itang chants, such as 'Worofes' make use of reoccurring text and rhythmic phrases that serve as mnemonic aids and as organisational motifs. In 'Worofes' one of these structural makers occurs in lines 4-6; these phrases (transcribed in Figure 5) are recited four times in the example.

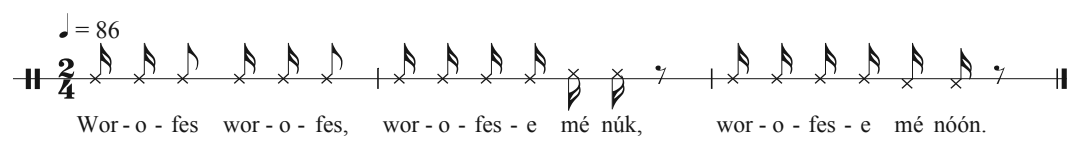

Figure 5. An excerpt of 'Worofes' (Searching look)

Both the content of the poetry (the language of itang) and the vocal delivery (as rhythmic recitation) mark 'Worofes' as a highly valued and powerful thread of cultural knowledge for Chuukese listeners. As that knowledge creates a space of contemplation and deep listening through performance, it offers a means of reflection on place, society, and politics.

\section{Reflection}

In this chapter I have explored two musical examples from Chuuk State in the Federated States of Micronesia that demonstrate the role of music in diplomacy and in maintaining cohesion in society. Both examples are from the chant repertory, but each presents a contrasting role in the establishment of peace. The chant 'Wélúmetaw', according to local histories, was created as a form of conflict intervention between two island communities divided by a dispute. Its present-day performance acts as a reminder of that conflict and, more importantly, the establishment of peace. Through its textual references and its linkages with stories that accompany it in cultural memory, 'Wélúmetaw' retells of the past as a means to bring people together in the present. In the second example, the rhythmic recitation called 'Worofes' is a formalised performance that was

29 A detailed accounting of itang language in the contexts of recitation is outside the scope of this chapter, but its general characteristics include: (1) phrases of eight morae; (2) standardised and recurring phrases; (3) phonemic parallelism and play through inserting and deleting vowels; (4) sonic play among word organisations; (5) the creation of new compound words; (6) a preference for the use of metaphor, allusion, and obfuscation; and (7) the inclusion of esoteric references, including named titles, spirits, and places. 
intended as part of the process of village or island diplomacy. In Chuuk, itang performance is an indigenous means of resolving conflict. 'Worofes' accomplishes this by taking listeners on an elaborate and imagined sea journey in order to mediate conflict though traditional moral authority, contemplation, and ideas of diplomacy.

Both of these music examples reinforce the importance of crossing boundaries and the reification of society through performance. According to Costa, 'formal structures of diplomacy are visible particularly in Indigenous protocols for encountering, communicating, and moving across boundaries, while diplomacy is also embedded in the way social orders are constructed and conceived' (2009: 62). This statement resonates closely with the two examples from Micronesia presented here. Both involve the cultural negotiation of encounter through boundaries of time and space: through the troubled seas between Pollap and Tamatam or in the imagined ocean journey of 'Worofes'. Both examples also are intended to move communities from a situation of conflict to a transformation of peace; thus both place a cultural emphasis on a stable and balanced community. While few studies have contextualised the role of music or dance in such situations in the Pacific region, future research may further demonstrate the power of performance in mediating conflict and articulating diplomacy. For the areas of Micronesia discussed in this chapter, chant performance brings a heightened awareness of the cultural past. It offers a social space with which to contemplate and affirm relationships vital for a cohesive and peaceful community.

\section{Acknowledgements}

My writing about 'Wélúmetaw' and 'Worofes' has been possible through the considerable generosity in knowledge shared with me by John Sandy, Rewi, Meichik Amon, and Fuchiko Pasen (all now deceased), Elias Sandy, Pedro Limwera, and conversations with many others. I thank Elias Sandy for assistance with the text transcription of 'Worofes', and Pedro Limwera and Elias Sandy for assistance with the text transcription of 'Wélúmetaw'. I also thank Inge van Rij for help in preparing the musicnotation transcriptions. Past research has been generously supported by the Wenner-Gren Foundation (Grant 7409), the University of Hawai' $i$ at Mānoa, Victoria University of Wellington, and the College of Micronesia-FSM, both Chuuk and National Campuses. 


\section{References cited}

Chipen, Takashy. 1979. Compiler. Uruon Chuk. Saipan: Trust Territory of the Pacific Islands, Omnibus Program for Social Studies-Cultural Heritage.

Costa, Ravi de. 2009. 'Indigenous Diplomacies before the Nation-State.' In Indigenous Diplomacies, edited by Marshall Beier, 61-78. New York: Palgrave Macmillan. doi.org/10.1057/9780230102279_5.

Diettrich, Brian, Jane Freeman Moulin, and Michael Webb. 2011. Music in Pacific Island Cultures: Experiencing Music, Expressing Culture. New York: Oxford University Press.

Elbert, Samuel H. 1972. Puluwat Dictionary. Canberra: The Australian National University.

Fischer, John L., and Ann M. Fischer. 1957. The Eastern Carolines. New Haven: Human Relations Area Files.

Flinn, Juliana. 1982. 'Migration and Inter-island Ties: A Case Study of Pulap, Caroline Islands.' PhD diss., Stanford University.

—_ 1990. 'We Still Have Our Customs: Being Pulapese in Truk.' In Cultural Identity and Ethnicity in the Pacific, edited by Jocelyn Linnekin and Lin Poyer, 103-26. Honolulu: University of Hawai' $i$ Press.

—_. 1992. 'Pulapese Dance: Asserting Identity and Tradition in Modern Contexts.' Pacific Studies 15 (4): 57-66.

- 2010. Mary, the Devil, and Taro: Catholicism and Women's Work in a Micronesian Society. Honolulu: University of Hawai'i Press.

Goodenough, Ward H. 1986. 'Sky World and This World: The Place of Kachaw in Micronesian Cosmology.' American Anthropologist 88 (3): 551-68. doi.org/10.1525/aa.1986.88.3.02a00010.

—_. 1995. 'A Traditional Micronesian Poetry.' Umanidát 3 (1): 78-84.

—_. 2002. Under Heaven's Brow: Pre-Christian Religious Tradition in Chuuk. Philadelphia: American Philosophical Society. 
Goodenough, Ward H., and Hiroshi Sugita. 1980. Compilers. TrukeseEnglish Dictionary. Philadelphia: American Philosophical Society.

Herzog, George. 1932. 'Die Musik auf Truk.' In Truk, edited by Augustin Krämer, 384-404. Ergebnisse der Südsee-Expedition 1908-1910, II B 5/2. Hamburg: Friederichsen, de Gruyter.

—. 1936. 'Die Musik der Karolinen-Inseln.' In Westkarolinen, edited by Anneliese Eilers, 263-350. Ergebnisse der Südsee-Expedition 1908-1910, II B 9. Hamburg: Friederichsen, de Gruyter.

Hezel, Francis X. 2002. 'Settling Disputes.' Micronesian Counselor 39 (15 January).

Hiatt, Lester R. 1986. 'Rom in Arnhem Land.' In Rom: An Aboriginal Ritual of Diplomacy, edited by Stephen A. Wild, 3-13. Canberra: Australian Institute of Aboriginal Studies.

Lessa, William H. 1980. More Tales from Ulithi Atoll. Berkeley: University of California Press.

Marshall, Mac, and Leslie B. Marshall. 1990. Silent Voices Speak: Women and Prohibition in Truk. Belmont, CA: Wadsworth Publishing Company.

McLean, Mervyn. 1999. Weavers of Song: Polynesian Music and Dance. Auckland: Auckland University Press.

Micronesian Music Project. 1979. Sound recordings (cassette and reel-toreel audiotapes), fieldnotes, and music texts (in Chuukese). Kim Bailey, project coordinator. Various performers and transcribers. Honolulu: University of Hawai' i Music Department, Ethnomusicology Archive.

O’Connell, John. 2010. 'An Ethnomusicological Approach to Music and Conflict.' In Music and Conflict, edited by John Morgan O'Connell and Salwa El-Shawan Castelo-Branco, 1-14. Urbana: University of Illinois Press.

Peck, William M. 1992. 'Chuukese Testament: Laws, Chronicles, Prayers.' Storyboard 2: 19-102. 
Petersen, Glenn. 2009. Traditional Micronesian Societies: Adaptation, Integration, and Political Organization in the Central Pacific. Honolulu: University of Hawai'i Press. doi.org/10.21313/hawaii/ 9780824832483.001 .0001 .

Riesenberg, Saul H., and Samuel H. Elbert. 1971. 'The Poi of the Meeting.' The Journal of the Polynesian Society 80 (2): 217-27.

Sandy, John, 2001. 'Pweruk.' Unpublished manuscript. Personal collection of Brian Diettrich.

Watson-Gegeo, Karen Ann, and Geoffrey White. 1990. eds. Disentangling: Conflict Discourse in Pacific Societies. Stanford, CA: Stanford University Press.

Wild, Stephen A. 1986. ed. Rom: An Aboriginal Ritual of Diplomacy. Canberra: Australian Institute of Aboriginal Studies.

__ 2006. 'Ethnomusicology Down Under: A Distinctive Voice in the Antipodes?' Ethnomusicology 50 (2): 345-52.

Wolff, Patrick M., and O. Randall Braman. 1999. 'Traditional Dispute Resolution in Micronesia.' South Pacific Journal of Psychology 11 (1): 44-53. doi.org/10.1017/S0257543400000742. 
This text is taken from A Distinctive Voice in the Antipodes: Essays in Honour of Stephen A. Wild, edited by Kirsty Gillespie, Sally Treloyn and Don Niles, published 2017 by ANU Press, The Australian National University,

Canberra, Australia.

dx.doi.org/10.22459/DVA.07.2017.07 